IX Congresso Brasileiro de Informática na Educação (CBIE 2020)

Anais do XXVI Workshop de Informática na Escola (WIE 2020)

\title{
The impact of serious games on the learning of students with Autism Spectrum Disorder
}

\section{Joseane Terto de Souza Uema ${ }^{1}$, Fabiana Leme de Oliveira ${ }^{2}$, Laíza Ribeiro Silva ${ }^{1}$, Armando Maciel Toda ${ }^{1}$, Seiji Isotani ${ }^{1}$}

\author{
${ }^{1}$ Instituto de Ciências Matemáticas e de Computação - Universidade de São Paulo (USP) - Campus \\ de São Carlos - Caixa Postal 668 - 13560-970 - São Carlos - SP - Brasil \\ ${ }^{2}$ CAIS - Centro de Atenção a Inclusão Social - Secretaria de Educação - Prefeitura Municipal de \\ Diadema - 9911-320 - São Paulo - SP - Brasil
}

joseane.terto@gmail.com, fabiana@inclutopia.com.br, laizaribeiro@usp.br, armando.toda@gmail.com, sisotani@icmc.usp.br

\begin{abstract}
With the increasing number of students with Autism Spectrum Disorder (ASD) being enrolled in the public education system, it is progressively necessary to think about differentiated pedagogical practices to assist in the learning of these scholars. From this angle, the usage of technologies can be an alternative for the teaching-learning process of distinct educational aspects, such as in the literacy process. For this reason, this paper utilized the game Mundo das Letras (World of Letters) to verify which would be the possible contributions to the learning of ASD students; the initial results revealed that serious games based on the cognitive psychology of reading can positively impact their learning.
\end{abstract}

Resumo. Com o número crescente de estudantes com Transtorno do Espectro Autista (TEA) sendo matriculados nas redes de ensino público, se faz cada vez mais necessário pensar em práticas pedagógicas diferenciadas para auxiliar na aprendizagem desses alunos. Nesse contexto, o uso de tecnologias podem ser um diferencial para o ensino-aprendizagem de diferentes aspectos educacionais, como no processo de alfabetização. Por conta disto, esse trabalho utilizou o jogo Mundo das Letras para verificar quais seriam as possíveis contribuições na aprendizagem de alunos com TEA, os resultados iniciais mostraram que os jogos sérios embasados na psicologia cognitiva da leitura podem impactar positivamente na aprendizagem deles.

\section{Introduction}

Each year the number of Autism Spectrum Disorder (ASD) students in ordinary schools increases at all stages of teaching. According to the School Census (Inep, 2019), there was a crescent of $89 \%$ of students included, in greater number in the public system. The inclusion of these students does not guarantee that schools are prepared to adapt their materials, curriculum, or teacher training. For example, in the public networks only 46\% (Inep, 2019) have accessibility feature, such as accessible rooms, sound signaling, among others. 
IX Congresso Brasileiro de Informática na Educação (CBIE 2020)

Anais do XXVI Workshop de Informática na Escola (WIE 2020)

Some of the main characteristics identified in ASDs are the delay in the development process, absence of social skills and verbal and nonverbal speech, in addition to the lack of attention in carrying out activities (OPAS, Brazil, 2017). Nonetheless, one of the important aspects to the educational development of every child, including those with ASD, is the literacy process, which is a complex task that requires several skills, along with cognitive ones. This is because teaching to read and write to students with ASD requires great educational stimulus, since if they are not encouraged correctly, they may end up losing the vocabulary that has already been acquired (Gobbo et al, 2019).

In literature, studies suggest that digital games can favor the learning of children with the disorder (Britto; Pizzolato, 2016; Neto et al, 2017). Additionally, research highlights that the use of tablets present positive outcomes, such as improvement in the knowledge of letters, written development and learning of sounds. There should also be considered the attention of the student, as games are interactive tools that can provide visual and sound stimuli to facilitate the acquisition of content (Silva et al, 2020).

It is imperative to consider that students with ASD can present visual thinking, predominantly images, so using varied resources for the literacy process is fundamental (Sampaio; Oliveira, 2017).

In fact, the initial learning of written languages is an area of education that has benefited from the evolution of technology, such as software and educational games. The creation and use of these programs should enable apprentices to have favorable teaching tools, assisting them in their learning of reading and writing (Souza, 2013).

Based upon the above, this work aims to explore the use of a serious game in the literacy process of students with ASD. Through a qualitative research, the game Mundo das Letras (Souza, 2013) is used on students from a public school. The objective is to verify how this game influences the student's learning and its impact on their routine.

\section{Theoretical Reference}

The cognitive psychology of reading is concerned with understanding the cognitive processes of reading and writing, as well as the acquisition of these processes by the learner. The recognition of written words allows the conditions of a highly interactive action between understanding the auditory and visual modalities of entering linguistic information. It is the science which seeks to describe and explain the ensemble of cognitive capacities (mental capacities of information processing) available to human beings (Morais, 1996).

Understanding the alphabetical principle of writing, which requires awareness that graphemes represent phonemes, is the essential step for the child to progress in their learning. The student needs to understand that the words we speak are constituted of units of sounds, the phonemes. When we read, we convert letter sequences into sounds. It is the cognitive processing that converts these sequences of letters into sounds and allows comprehension. Fluent and comprehensive reading is based on the domain of the alphabetical code (Maluf, 2013).

The term "phonological consciousness" can be applied in a generic way to refer to the ability to analyze words in oral language according to the different sound units that compose them. This notion has been studied from evidence, aiming to evaluate the subject, either to apprehend judgements on the sound characteristics of words (size, similarity, difference) or 
IX Congresso Brasileiro de Informática na Educação (CBIE 2020)

Anais do XXVI Workshop de Informática na Escola (WIE 2020)

to isolate and manipulate phonemes and other suprasegmental units of speech, such as syllables and rhymes (Souza, 2013).

Thus, a serious game was developed, with the purpose of not just entertaining, but functioning as a teaching tool (Abt, 1987) and as from this conception Mundo das Letras was created, gathering the ludic character and literacy education, specifically, learning the alphabetical principle.

Serious games can be used for learning, but need to be planned, developed, evaluated, and utilized for this sole purpose by the apprentice (Rocha, 2017).

However, in the development of these games there are challenges that must be considered, such as those related to: (1) characteristics of the final product - which requires balancing pedagogical aspects (content, evaluation, feedback) and gameplay (challenge, control, immersion); (2) inclusion of abilities to be taught, trained and evaluated; (3) integration of different professionals in its construction; (4) systematization and standardization of artifacts and processes in its development; (5) reuse and extension of referred artifacts; (6) evaluation and (7) validation of both learning/training and serious game (Rocha, Bittencourt e Isotani, 2015).

Some studies have already developed technologies for autistic students in order to assist in the learning process. Among them, we can mention Silva, Soares and Benitez (2017) who have developed the digital environment - mTEA, in which activities could be elaborated based on the autistic child's curriculum through web software. The mTEA consisted of three software: i) a server that stores data in the cloud (mTEA-Server), ii) web software (mTEAWEB) used for the elaboration of custom activities and iii) app for tablet/smartphone. For this study, a professional with a degree in Psychology and Pedagogy, who had been working in the field for eight years in the area of special education was selected, and three ASD students.

Dantas et al (2019) developed a serious game, Michelzinho, to assist in teaching social and emotional skills to people with Autism Spectrum Disorder and intellectual disability, to recognize and express basic emotions such as: joy, sadness, anger, disgust, surprise and fear. The game was applied in the period of six months; user information, rounds played and improvements to the game were collected. In this time span, more than 250 thousand rounds were played by more than 2 thousand players.

\section{Materials and methods}

To develop this research, a qualitative approach was chosen, as this type of approach consists of making unstructured data into information from the context in which it is being applied (Corbin; Strauss, 2014). According to Corbin and Strauss (2014), this type of study can be divided into three stages, being: (i) the problem definition; (ii) analysis; and (iii) inference about the object of study.

In the context of this study, the objective is to explore the use of the Mundo das Letras and its educational impacts on students with ASD. The game was chosen on convenience (the authors had access to the game and its source code) and as its development was based on consolidated theories of cognitive psychology of reading. The analysis was performed through observations made by the professor and researcher, and inferences were made based on these observations. 
IX Congresso Brasileiro de Informática na Educação (CBIE 2020)

Anais do XXVI Workshop de Informática na Escola (WIE 2020)

Mundo das Letras was developed based on the cognitive psychology of reading, aiming at the development of a tool for teaching the alphabetical principle, the first and primary step towards success in literacy (Souza, 2013).
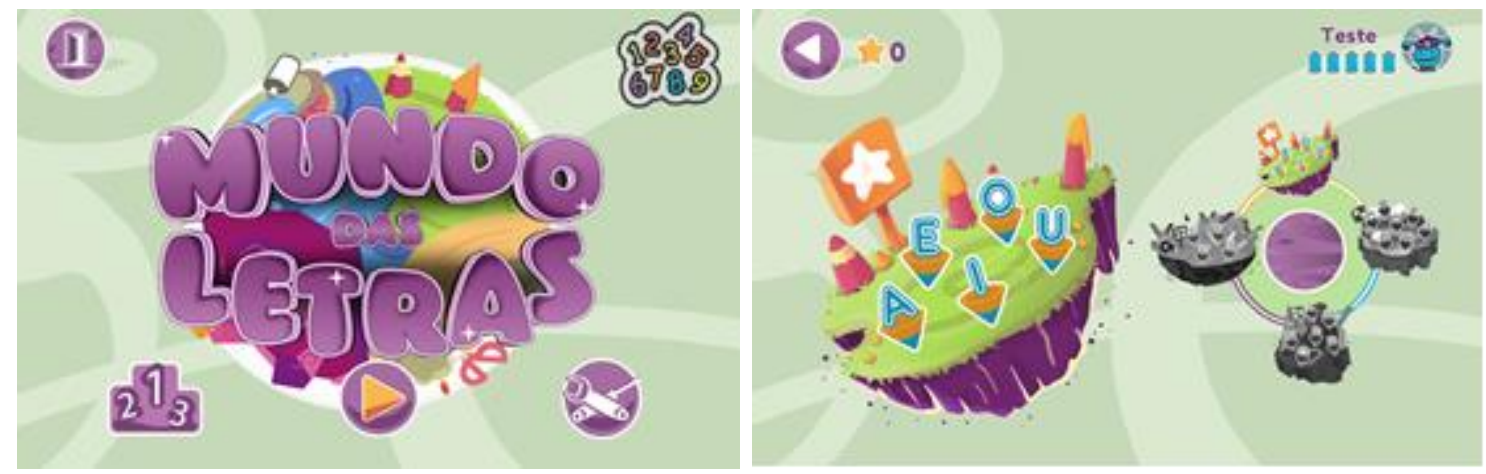

Figure 1. Screens of Mundo das Letras

Mundo das Letras was designed as an intergalactic game with fun and colorful characters that live in four worlds composed of the 26 letters of the alphabet. In addition to sounds (dubbing of the words and actions on the game) and images that together contribute to literacy in a ludic and intuitive way, the game was developed using the Unity $3 \mathrm{D}$ tool that utilizes C\# as its main programming language.

Each level in the game is represented by a small planetoid (Figure 1), which represents a group of letters. The goal is to progress through the four worlds (the levels), accomplishing the tasks to know all letters, associating the sounds of the letters to the initial sound of a selected word, integrating the game.

Additionally, there is a bonus level formed by the letters $\mathrm{K}, \mathrm{X}, \mathrm{W}$ and $\mathrm{Y}$ with words in Tupi Guarani, in which there is no punctuation (gain or loss), as the goal is for students to acquire knowledge on writing and the meaning of indigenous words. On top of that, this level complies with Law $n^{\circ} 11.645 / 08$, which inserts Afro-Brazilian and indigenous history and culture in the school curriculum, in addition to encouraging knowledge of the vocabulary of the Brazilian indigenous matrix.

The game-activity interface suggests identifying which words start with the phonemes associated with the selected letter, to help the student to identify the initial sound of each word with the sound produced by each letter. This activity is focused on the literacy process. Thus, the skills associated with the activity are:

1) Knowledge of (reading) and (name) of the letters: this knowledge must not come from an automatic sequence of alphabetic memories but knowledge and recognition of graphemes and the name of said graphemes.

2) Phonological consciousness: involves a skill in which a child learns to listen with the neurological ear, associating sounds and letters and with these transpositions between the auditory signals, corresponding to graphic signals, coming from the articulatory units of speech. 
IX Congresso Brasileiro de Informática na Educação (CBIE 2020)

Anais do XXVI Workshop de Informática na Escola (WIE 2020)

\subsection{Application}

The application took place from April to June 2019, totaling three months, twice a week, each session being of 60 minutes, using a tablet as a technology device. The research took place in a special room for students with ASD (Autism Spectrum Disorder) of the Center for Attention to Social Inclusion (CASI), an inclusive educational support service provided by the Municipal Secretary of Education from Diadema - São Paulo.

The operation happened at night, after the hours of the regular classrooms, on specific days for each student, with attendance in pairs or individually, according to each student's diagnosed need.

The targeted audience of these consultations are students from the Municipal Network of Public Schools from Diadema - São Paulo, with a diagnosis or diagnostic hypothesis of Autistic Spectrum Disorder. In general, the objectives of a Resource Room are:

- Evaluate and seek different strategies for learning;

- Globally stimulate the fundamental basis for learning;

- Accompany and guide family members and/or guardians in the pedagogical process.

The choice to realize the study in the first semester was because it is during this period that the initial literacy abilities are developed. Thus, before the students used Mundo das Letras, a pre-test was applied to check the level of literacy and learning that each of the students fit since the same test would be applied in the post-test to evaluate progress in learning literacy before and after having contact with the game.

\subsection{Class Characterization}

The group of the Center for Attention to Social Inclusion consists of seven classrooms that operate in three periods: morning, afternoon, and night. The class selected for the application was at night and was composed of a teacher and 19 students with individualized or double attendance. The age of the students was between 4 and 10 years old and their diagnosis follow:

- 11 diagnosed with Autism Spectrum Disorder (ASD);

- 02 diagnosed with Intellectual Deficiency;

- 02 diagnosed with Attention Deficit Hyperactivity Disorder (ADHD);

- 04 in the process of diagnosis of ASD.

After the application of the pre-test, the data collected on the literacy process were:

- 03 literate students, text producers;

- 02 literate students, with difficulties in writing sentences and texts;

- 02 students starting activities of attention and presentation of writing;

- 12 in the literacy process.

Mundo das Letras was also applied to literate students, as a way of verifying what gain would they have in their learning but focused on students in the literacy process. 


\section{Results and Discussion}

The game was used on 18 students, as one of them did not accept contact with the tablet. It was used in a complementary way to the activities developed by the classroom teacher, that is, the research was organized along with the planning of activities to integrate the game as a complementary resource of school activities, according to the objective for each student.

Seen as it is an interactive resource, the acceptance to perform the activity was very high, and only one student, committed to physical and cognitive issues, was unable to respond favorably to the use of the tablet.

It was very important to observe the gradual expansion of the student's concentration span, the ease in recognizing the objectives of the game (intuitive interface), and the joy in carrying out the activity since the ludicity is fundamental in learning.

Due to the characteristics of each student, it was often necessary to use concrete elements, associating the letters of the game with rubberized letters, for example (Figure 2). In other moments, it was observed that students had difficulties in establishing contact through tact, and requested the help of the conducting teacher or the researcher to complete the activity, holding their hands, possibly indicating the search for a social relationship of empathy.
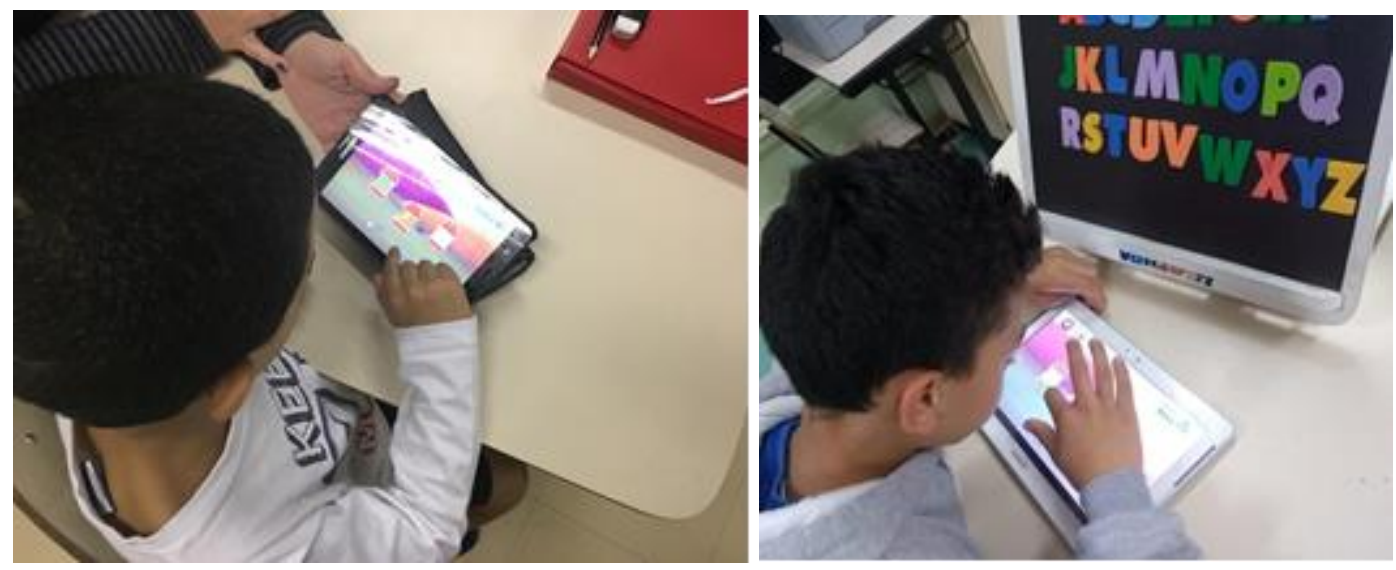

Figure 2: Children playing Mundo das Letras

Using the game Mundo das Letras, integrated with the activities, provided an expansion of the strategies and resources that we need to use in the teaching of students with ASD. Thus, after three months of contact with the game and applying a post-test, we were able to observe the following advances in learning:

- To the literate students, the visual stimulus of the activity brought on moments of research and writing of different words, where it was possible to explore the orthographic rules, with the use of dictionaries associated with the game;

- The application features words in Tupi Guarani, which aroused curiosity, expanding the dialogue and the desire to learn more about native people;

- In students in the literacy phase, there was an increase in recognition of the letters of the alphabet and their association with words;

- An observed advance was in the time spent in carrying out the activity. As it is an interactive resource, we use it in a complementary way to the use of concrete 
IX Congresso Brasileiro de Informática na Educação (CBIE 2020)

Anais do XXVI Workshop de Informática na Escola (WIE 2020)

references, such as rubberized letters, whiteboard and pen, table with syllables and activity notebook;

- In students with little to no verbalization, the indication of the figures and interactivity favored communication, expanding vocabularies and developing fine motor skills due to the execution of the movement;

- Another motivating factor is the positive reinforcement and praise in hits; an increase in interest and time dedicated to the execution of activities was observed, gradually feeding into the urge to get it right to receive positive reinforcement.

To the classroom teacher, "those who work in the literacy of children with disabilities or autism are always challenged to seek different resources and methodologies, seen as often, the literacy routes known to typical children (without disabilities or disorders) do not apply to them. Games such as Mundo das Letras complement our performance with a ludic and interactive resource and, therefore, are fundamental to stimulate memory and recognition of the relationship between sounds and letters (grapheme and phoneme), which is so important in the literacy process of students with ASD. Aggregating the use of the game with conventional activities and elaborating other didactic sequences from the game helped me to promote greater engagement in the activity, with that the utilization, the content fixation, and the attention span was much longer".

Thus, the observed was that educational games can help motivate and positively impact the learning of students with ASD. In Mundo das Letras, the incentive to continue learning was present through a scoring system and congratulations when the student got a letter or phrase correctly, making the learners continue to play even when they made mistakes, which helped in their literacy process.

It is essential for the country's economic and social growth that children learn the essence of literacy, which is to read and write fluently, so that they can become "readers of the world" (Freire, 1988). It is not possible to admit in our society the existence of "functional illiteracy" (Morais, 1996) or functional illiterates, who are characterized by the inability to understand or produce a written message (Foucambert, 1994), thus guaranteeing the rights of learning and inclusion of children and young people with ASD.

For this reason, public policies need to be attentive to research that studies the most effective way of teaching how to read and write, as social equality begins by offering fluent reading and writing opportunities to all learners. In this sense, the cognitive psychology of reading and computer studies applied to education can contribute to research and work that carries out. In addition to pre-tests and post-tests, redemption tests should be applied to see what happened to the learning after a certain period.

As Freire (2002) recalls, knowing is a task of subjects, not objects. It is a subject, and only as a subject, that one can truly know. That is why, in the learning process, only truly learns one who has appropriated what has been learned. The teaching and learning process, in this context, can occur with the use of educational games, such as Mundo das Letras, at the beginning of the literacy of students with ASD.

It is known that the process of teaching and accessing the learning of students with autism spectrum disorder is quite complex and that many are rejected by conventional schools. We need to enlarge our resources by bringing different experiences and expanding our assessment. Interactive resources have great possibilities in the development of learning and are essential for autistic students to fully develop their skills and competencies. New means 
IX Congresso Brasileiro de Informática na Educação (CBIE 2020)

Anais do XXVI Workshop de Informática na Escola (WIE 2020)

and forms are valid in the classroom, only if of the main objectives expected from school is present: learning.

\section{Conclusions and Future Work}

This work presented a qualitative study involving the exploration of the game Mundo das Letras to assist in the literacy of children with ASD. When using the developed educational game, Mundo das Letras, students, in addition to having fun, were taught on the alphabetical principle, seen as it is a fundamental concept to the process of learning to read and write. This is precisely the sole purpose of developed educational games, as this knowledge can predict success in the literacy process.

This study contributes to the literature by providing a tool that, through our analysis, can be used to assist in pedagogical practices involving children with ASD. As of future work, we intend to carry out further research with more students with ASD in a quantitative way. Thus, we will obtain new information about their learning process and how we can develop new technologic tools for different aspects of learning, such as the literacy of autistic students.

When we think of education today, it is imperative to consider how our children are interacting with a world full of technology. In this context, children with disabilities or autism are also digitally connected and use technology in a very intuitive way. Incorporating technological use into our pedagogical practice is essential; activities on the tablet or cell phone should be part of our planning and teaching activities.

\section{Acknowledgements}

The authors would like to thank FAPESP (Project 2016/02765- 2), Capes and CNPq for the funding provided.

\section{References}

Abt, Clark C. (1987). Serious games. University press of America.

Brasil. Lei no 11.645, de 10 de março de 2008 (2008, 10 de março). Estabelece as diretrizes e bases da educação nacional, para incluir no currículo oficial da rede de ensino a obrigatoriedade da temática "História e Cultura Afro-Brasileira e Indígena”. Disponível em: <http://www.planalto.gov.br/ccivil_03/_Ato2007-2010/ 2008/Lei/ L11645.htm>. Acesso em jul. de 2020.

Britto, Talita; Pizzolato, Ednaldo Brigante. (2016). GAIA: uma proposta de um guia de recomendações de acessibilidade de interfaces Web com foco em aspectos do Autismo. Anais do XXVII Simpósio Brasileiro de Informática na Educação (SBIE 2016). Disponível

em: < https://www.brie.org/pub/index.php/sbie/article/view/6767/4652>. Acesso em jul. de 2020 .

Capucha, L (2008). Unidades de ensino estruturado para alunos com perturbações do espectro ao autismo - Normas orientadoras. Direcção Geral de Inovação e de Desenvolvimento Curricular. Lisboa: MEC.

Caron M. J. et al (2004). Do high functioning persons with autism present superior spatial abilities? Neuropsychologia. Disponível em: $<$ https://pubmed.ncbi.nlm.nih.gov/14728920/ > . Acesso em jul. de 2020. 
IX Congresso Brasileiro de Informática na Educação (CBIE 2020)

Anais do XXVI Workshop de Informática na Escola (WIE 2020)

Corbin, Juliet; Strauss, Anselm (2014). Basics of qualitative research: Techniques and procedures for developing grounded theory. Sage publications.

Cosenza, R. M., \& Guerra, L. B. (2011). Neurociência e educação: como o cérebro aprende. Porto Alegre: Artmed.

Dantas et al (2019). Michelzinho: Jogo sério para o ensino de habilidades 'emocionais em pessoas com autismo ou deficiência intelectual. Disponível em: <https://www.brie.org/pub/index.php/sbie/article/view/8772/6330 >. Acesso em jul. de 2020.

Dehaene, S. (2012). Os neurônios da leitura: como a ciência explica a nossa capacidade de ler. Porto Alegre: Penso.

Freire, P. (1988). A importância do ato de ler: em três artigos que se completam. São Paulo: Autores Associados.

Freire, P. (2002). Extensão ou comunicação? (12a ed.). Rio de Janeiro: Paz e Terra.

Foucambert, J. (1994). A leitura em questão. Porto Alegre: Artes Médicas.

Gobbo, M. R. M.et al. (2019). Aplicativo para Ganho de Vocabulário e Auxílio na Alfabetização destinado às Crianças com Transtorno do Espectro Autista. Disponível em: $<$ https://www.br-ie.org/pub/index.php/sbie/article/view/8839/6397>. Acesso em jul. de 2020 .

Inep. Censo Escolar (2019). Disponível em: <http://portal.inep.gov.br/web/guest/ resultados-e-resumos >. Acesso em jul. de 2020.

Maluf, M. R. (2013). Ensinar a ler: progressos da psicologia no século XXI. In Anais do XXXIV Congresso Interamericano de Psicologia. Brasília, DF. Recuperado de http://certificados.sip2013.org/. Acesso em jul. de 2020.

McGuinness, D. (2006). O ensino da leitura inicial: o que a ciência nos diz sobre como ensinar a ler. Porto Alegre: Artmed.

Morais, J. (1996). A arte de ler. São Paulo: Editora UNESP.

Neto, João Coelho et al. (2017). Autismo e Tecnologia: um mapeamento sobre as tecnologias para auxiliar o processo de aprendizagem. Revista Primus Vitam $\mathrm{n}^{\circ}$ 9. Disponível em: $<$ http://delphos-gp.com/primus_vitam/primus_9/JoaoCoelho_Marilia vBazan.pdf $>$. Acesso em jul. de 2020.

OPAS/OMS Brasil. Transtornos do espectro autista, (2017). Disponível em: 〈https://www.paho.org/bra/index.php?Itemid=1098>. Acesso em jul. de 2020.

Rocha, Rafaela Vilela da (2017). Critérios para a construção de jogos sérios. Disponível em: < https://www.br-ie.org/pub/index.php/sbie/article/view/7623/5419>. Acesso em jul. de 2020 .

Rocha, Rafaela V.; Bittencourt, I. I.; Isotani, S. (2015). Análise, Projeto, Desenvolvimento e Avaliação de Jogos Sérios e Afins: uma revisão de desafios e oportunidades. Disponível em: < https://br-ie.org/pub/index.php/sbie/article/view/5342 >. Acesso em jul. de 2020.

Rodrigues, Janine Marta Coelho; Spencer, Eric (2015). A Criança Autista: um estudo psicopedagógico. 2. ed. Rio de Janeiro: Wak Editora.

Sampaio, C. M. T.; Oliveira, G. F (2017). O Desafio da Leitura e da Escrita em Crianças com Perturbação do Espectro do Autismo. Id on Line: Revista Multidisciplinar e de Psicologia, v. 11, n. 36, p. 343-362. Disponível em: $<$ https://idonline.emnuvens.com.br/id/article/view/796> Acesso em jul. de 2020 
IX Congresso Brasileiro de Informática na Educação (CBIE 2020)

Anais do XXVI Workshop de Informática na Escola (WIE 2020)

Schwartzman, J. S; Araújo, C. A. (Orgs.). Transtornos do espectro do autismo: Conceitos e generalidades. São Paulo: Memnon. 2011.

Silva, Laiza Ribeiro et al. (2020). Computational approachesfor literacy of children with autism: $\quad$ systematic mapping, Interactive Learning Environments. $\quad$ DOI: $<10.1080 / 10494820.2020 .1780267>$. Acesso em jul. 2020.

Silva, Martony Demes da; Soares, André Castelo Branco; Benitez, Priscila (2017). Ambiente Digital para Ensino e Acompanhamento Personalizado de Estudantes com Autismo: proposta com Uso de Dispositivos Móveis. Disponível em: $<$ https://www.br-ie.org/pub/index.php/sbie/article/view/7633/5429 >. Acesso em jul. de 2020 .

Souza, J. T. de. (2013). Mundo das Letras: um aplicativo para ensinar o nome e o som das letras a crianças falantes do português do Brasil (Dissertação de Mestrado). Pontifícia Universidade Católica de São Paulo, São Paulo.

Snowling, M. J., \& Hulme, C. (2013). A ciência da leitura. Porto Alegre: Penso.

Sternberg, R. J. (2010). Psicologia cognitiva. São Paulo: Cengage Learning.

Tunmer, W. E. (2013). Como a ciência cognitiva forneceu as bases teóricas para a resolução do "grande debate" sobre métodos de leitura em ortografias alfabéticas. In: M. R. Maluf, \& C. Cardoso-Martins (Orgs.). Alfabetização no século XXII: como se aprende a ler e a escrever (pp. 124-137). Porto Alegre: Penso. 